獣 医 麻 醉 第11号 67-72 (1980)

Jap. J. Vet. Anesth. No. 11 67-72 (1980)

\title{
技術講 座
}

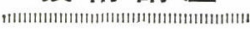

\section{ラットの保定と麻 酔}

保定にしろ麻酥にしろ動物実験を行なら以上は日常茶 飯事であるはずであったが，さて文章にしょうとすると 様子が異なり, 説明できないあるいは理解できない問題 が山積している。例觉ば著者は動物実験を行ならといら ことで麻醉を考光, それに馴らされているせいか, 動物 の臨床家の保定や, 麻酔はきわめて慎重で苟り丁寧であ る。しかし同じ臨床家であってもとトの臨床家の実験動 物の扱いは乱暴た゚と思うことがしぱしばある。これは動 物とヒトの生命の重みの違いなのか, 岗るいは動物実験 を行なら上で実験条件を単純化しなければならないため なのか理解できない。妨そらく実験条件を単純化して目 的の結果を明白にとら光よらとするためといらよりむ， 失敗はやりな技せるといら安易さが加味されているので はないた゚ろらか。著者もその点では反省している。

\section{I 取り扱い}

ラットを扱う時には，まずラットの性質を知って预か なければならない。そしてその性質を有効に利用すると 扱い易いことが多い。すなわわ，(1)ラットに不安や恐怖 感を与光るような音など, 環境の急激な変化を避ける。 (2)隠れる物の多い場所で逃亡させると性質が荒くなり野 生化する傾向がある。(3)四肢が床に着いている時に尾を 後方へ引くと前方に逃げようとして抵抗する。(4)さらに それを無理に後方に引くと尾の皮膚がすっ涪りとむけて しまう。(5)ヒトの体にラットの頭部を上にして四肢でし がみつかせると落ら着き, 手でラットの背を包むように やさしく押えるとさら落ち着く。

\section{II 保 定}

保定には日常の飼育管理や検査のための保定から彮療 飞招沙る保定, 実験のための保定, 岕るい法試験枋料採 取のための保定など多彩である。

\footnotetext{
* 東北大学医学部 動物実験施設
}

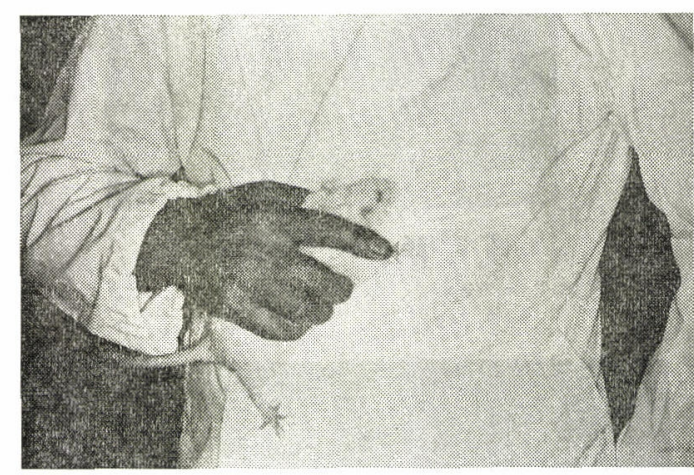

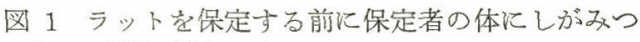
かせて落ち着かせる

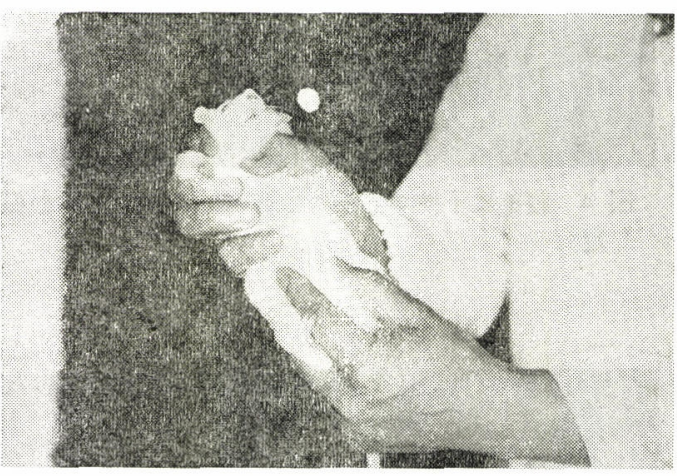

図 2 掌で背部から包むよらにし, 腋下から䫇下に 保定者の母指進め, 示指を対側の肩から顎下に 回わし, 示指と中指の間汇ラットの腕を挾む. 腹 部の触誩

1. 手汇上当保定 (図 2 6)

2. 器具による保定
a) 無麻酔保定（図 7 9)
b) 麻酔下の保定（図 10１4） 


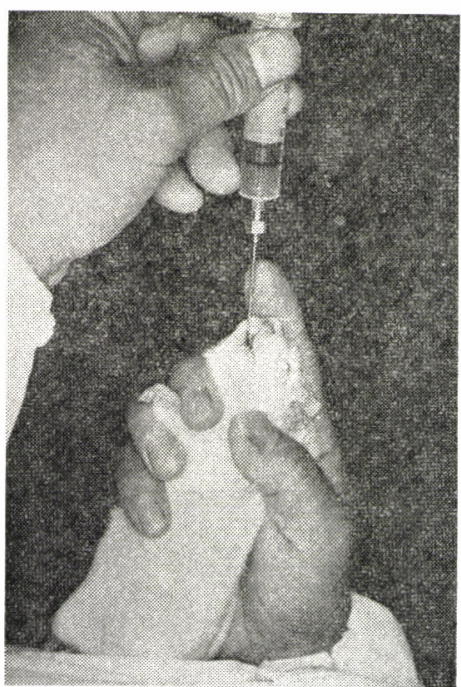

図 3 経口投与のための保定

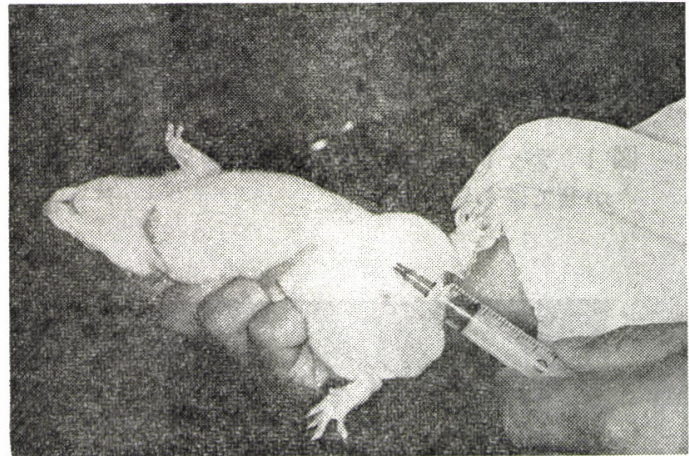

図 4 腹部皮下投与あるい:腹腔内投与のための保 定

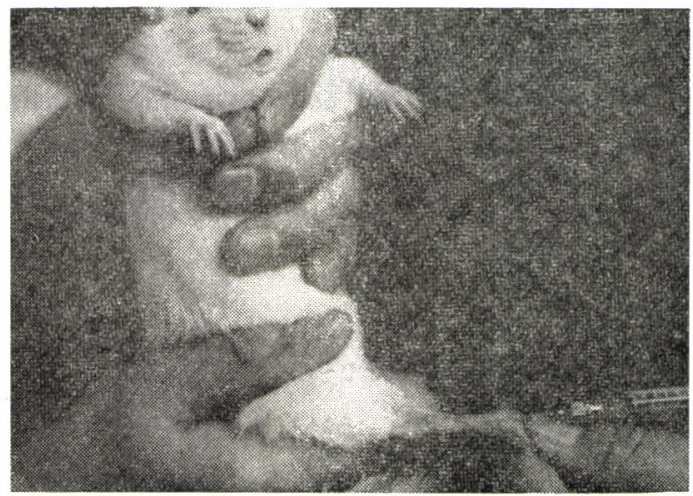

図 5 背中足静脈を用いた静脈内投与の保定

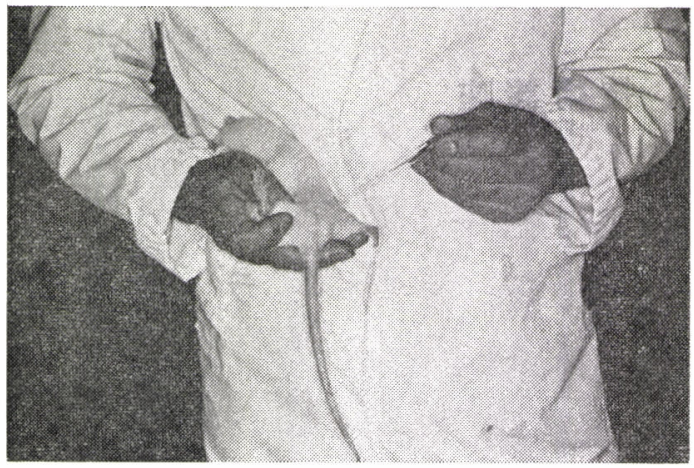

図 6 胵垢採取の保定

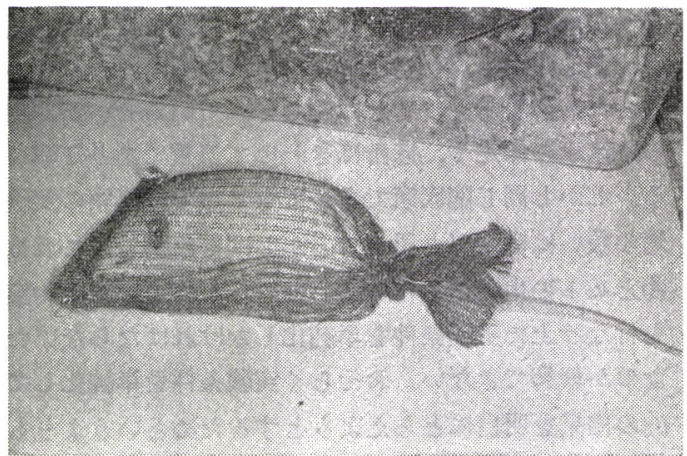

図 7 袋による保定。材料は布でも良いがミカンや クリなどを大れた網目の細かい空袋を消毒して用 いると便利である

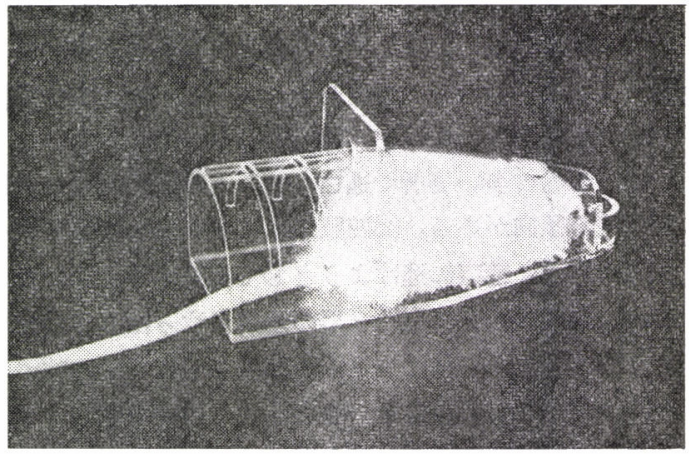

図 8 プラスチック保定器

\section{III 麻 酔}

局所麻酔は他の動物とほぼ同様であるので本稿に拈い ては全身麻酔についてのべる。

全身麻醉では実験動物の処置と臨床に拈ける処置とで 大変異なる。動物実験ではほとんぞ前処置をしないこと 


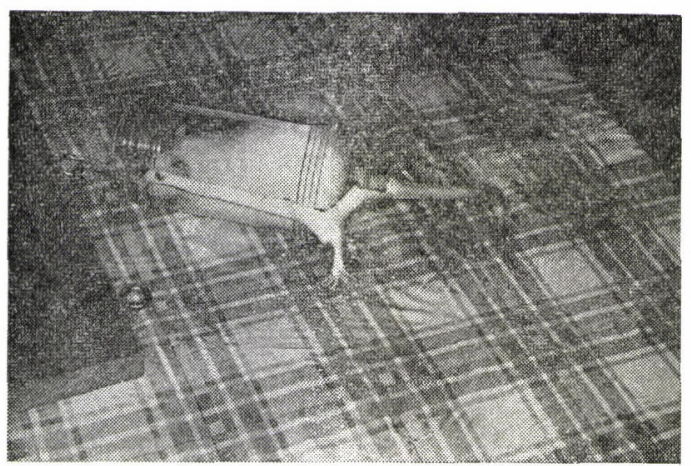

図 9 プラスチック試薬瓶を改造した保定器

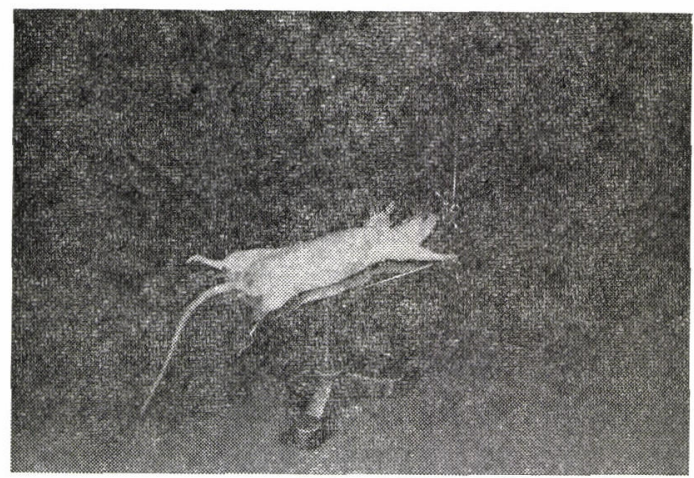

図 10 金属台保定器

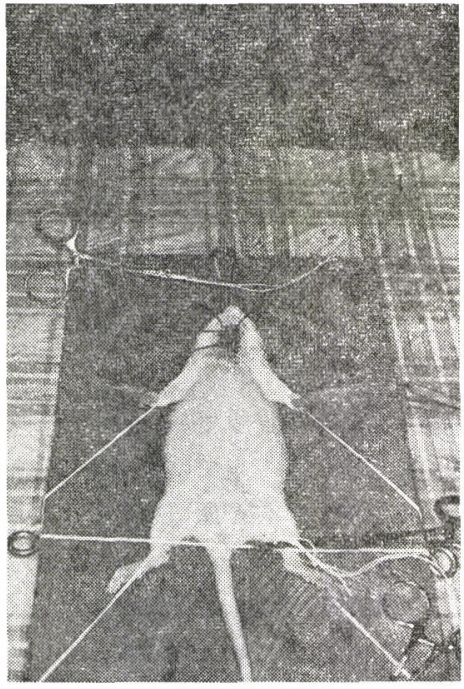

図 11 背位保定。下垂体摘出（顠静脈からの採血, リンパ管，原管，胆管などのカニューレイション も可能である)

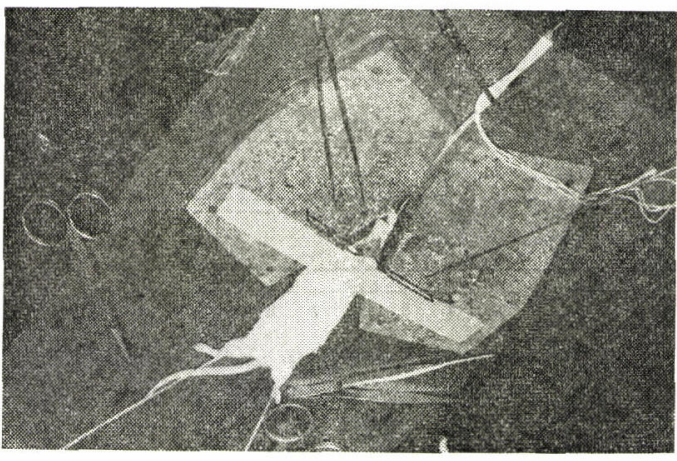

図 12 腹位保定，嗅球摘出（松下体，卵栄，副腎の 摘出可能)

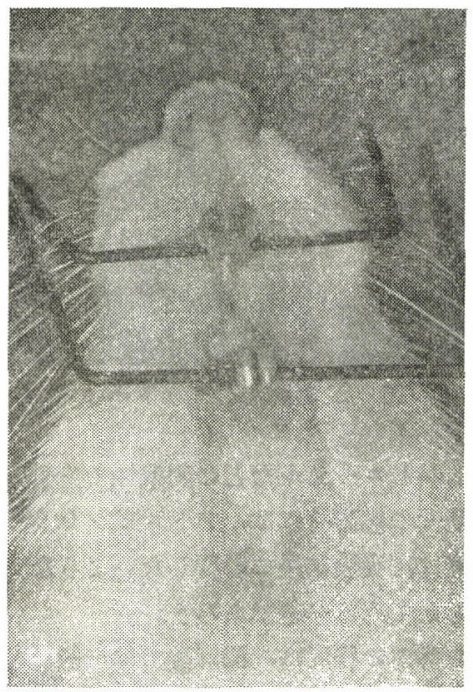

図 13 背位保定歯の処置

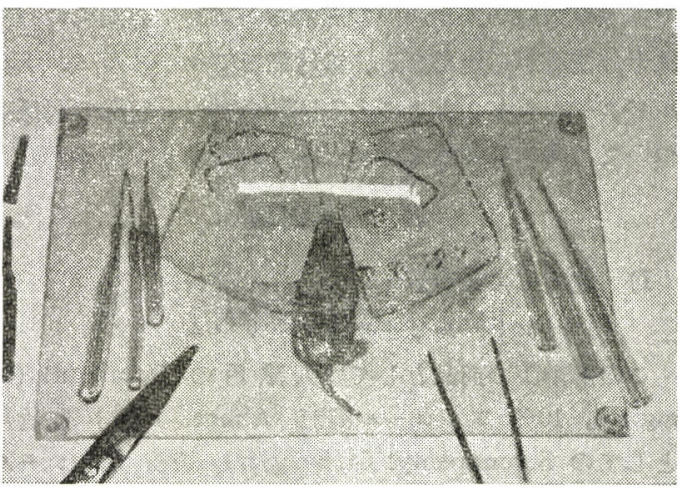

図 14 新生仔の保定。下垂体摘出(セロテープで保 定） 


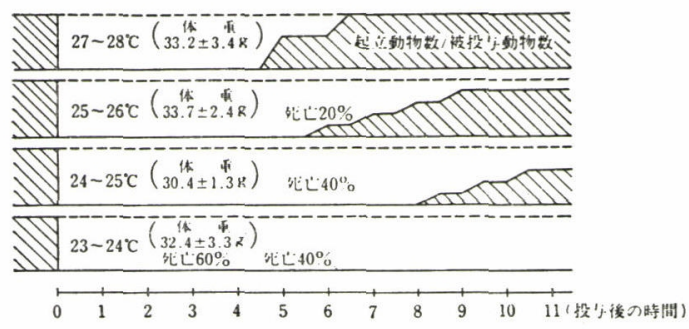

図 15 Nembutal 腹腔内投与 $(100 \mathrm{mg} / \mathrm{kg})$ による 薬理効果と温度条件の関係 (岡本)

(湿度 : 50〜60\%，動物：IVCS 系雉マウス，90〜 100 日齢, 各群 5 匹)

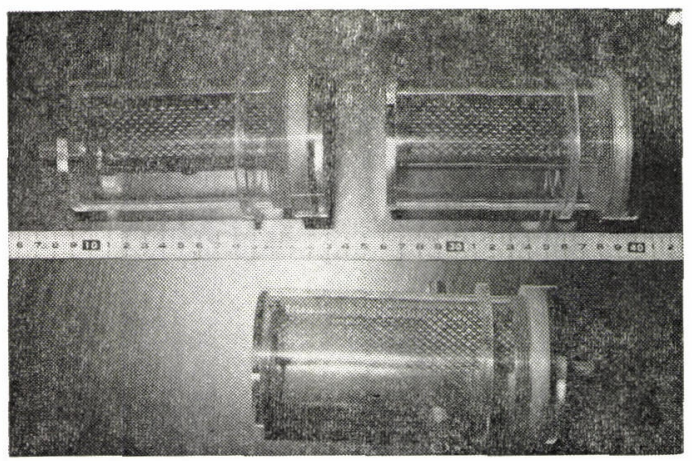

図 16 ガス吸入用ラットホルダー

が多い。しかしニーテルなどの刺戟性の麻酔剤を用いる 場合や長時間の麻酔時には, アトロピン $0.05 \mathrm{mg} / \mathrm{kg} な$ どの前処置は，実験結果に影響しないような方法で行な うことも考えてみるべきであろう。

ラットの麻䣲の程度は, 深麻酔では一般に背位に置い ても起き上がろうとはせず，頭部を動かそうともせず， 瞳孔の縮小，痛覚消失などイスやネコのそれと同様であ る。またマウスやラットのよらな小型の動物では，体温 や水分の放散が大きいので麻酔時の室温や湿度について は十分注意が必要である。参考あでにマウスのペントバ ルビタールナトリウムによる麻酔の覚醒と室温の関係に ついて，岡本の成績を示すと図 15 の通りである。

\section{1. 一般麻酔}

\section{1) 注射による麻酔}

a) ペントバルビタールナトリウム

この麻酔薬の商品としては人獣用の Nembutal (50 $\mathrm{mg} / \mathrm{ml}, 10 \%$ アルコール溶液, Abbott Lab.) 動物用 としての Somnopentyl $64.8 \mathrm{mg} / \mathrm{ml}, 10 \%$ アルニール 溶液, Pitman-Moore) が発売されている。本剤はラッ トにおいてきわめて良好な麻酔が得られるために若干の

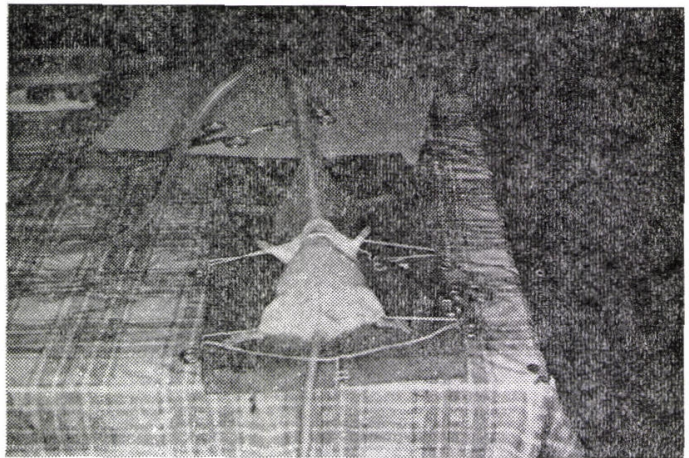

図 17 プラスチックロートを改良した吸入マスク

体温下降，血圧の低下などがあっても推奖され，好んで 使用されている。投与量は目的によって異なり，下垂体 摘出や卵巣摘出などの手術では $30 \mathrm{mg} / \mathrm{kg}$ の腹腔内投 与，中枢抑制（下垂体ホルモン放出抑制など）は40 $\mathrm{mg} / \mathrm{kg}$ の腹腔内投与を行なら場合が多い。その他長時 間の麻酔で実験終了後, 回復の必要がない実験には 60 $80 \mathrm{mg} / \mathrm{kg}$ の皮下投与も行なわれている。例兄ば還流実 験，腸管マグナス，循環実験などがとるである。

臨床飞和汓る使用は前処置和よび導入麻醉を十分に儿 て,できるた゚け麻酔薬量を少なくし，20３0 mg/ $\mathrm{kg}$ 程 度の腹腔内设与をするかあるいは $15 \sim 20 \mathrm{mg} / \mathrm{kg}$ の静 脈投与で手術適応の麻醉程度が得られれば安全である。 参考までに麻醉量と致死量を示すと表 1 のごとくであ る。

表 1 Wistar Imamichi rat 汇拈けるネンブタール

の麻酔量と致死量。 $24^{\circ} \mathrm{C}$ に尔ける結果

\begin{tabular}{ll|c|c|c}
\hline 投与ルート & 致死量 & 浅麻酔量 & 深麻酔量 \\
\hline 皮 & 下 & $200 \mathrm{mg} / \mathrm{kg} \leqq$ & $40 \mathrm{mg} / \mathrm{kg}$ & $50 \sim 60 \mathrm{mg} / \mathrm{kg}$ \\
\hline 腹 腔内 & $100 \mathrm{mg} / \mathrm{kg} \leqq$ & $20 \mathrm{mg} / \mathrm{kg}$ & $30 \sim 40 \mathrm{mg} / \mathrm{kg}$ \\
\hline 静 脈内 & & $15 \mathrm{mg} / \mathrm{kg}$ & $20 \sim 30 \mathrm{mg} / \mathrm{kg}$ \\
\hline
\end{tabular}

b) 塩酸アタミン（ケタラール）

本斉は表 2 のごとくラットでは投与量によって若干の 興奮を伴う。また左右に体や頭部をゆっくり振るなどの 症状を示し, 眼瞼反射の消失が得にくく, 投与量を増す と一挙に仮死期に移行する。また表 3 のごとく深麻酔量 と致死量が非常に接近しているので使用しにくい面があ る。乙か乙賞醒の良い点ではやはり高く評価できる。例 党ばペントバルビタールナトリウムの使用量を少なくす る意味での併用とか, 塩酸ケタミン導入後フローセンで 


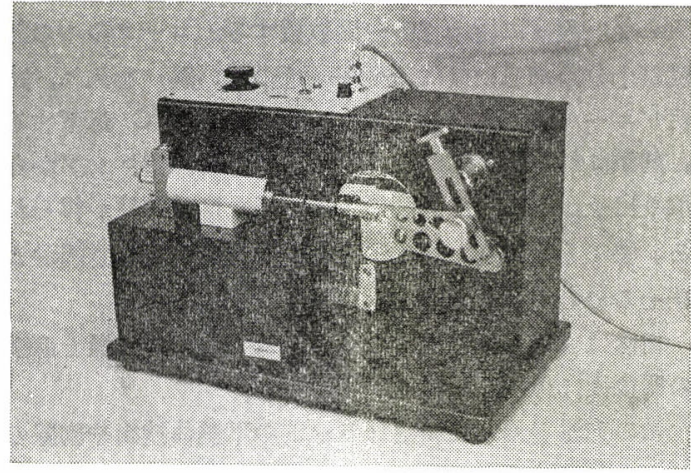

図 18 ラット，モルモット用人工呼吸器 (日本クレア， SN-480・7 型)

麻醉をするとか，あるいは筋弛緩剂であるサクシニール ニリンの安全量の前処置 (呼吸停止に注意)など該試み るべきである。

表 2 塩酸ケタミンの薬理作用と動物種 (CHEN, G の成績を一部修正)

\begin{tabular}{|c|c|c|c|c|c|}
\hline 動物種 & 興奮 & 強直 & 麻䣷 & 痤睜 & 持続 \\
\hline ラット & + & + & 不十分 & - & 短 \\
\hline モルモット & - & + & - & - & 短 \\
\hline ウ サ ギ & - & + & - & - & 短 \\
\hline ネ & - & + & + & まれ & 短 \\
\hline イ & $-(+?)$ & + & 不十分 & + & 短 \\
\hline
\end{tabular}

表 3 Wistar Imamichi rat に打ける塩酸ケタミン の麻酔量と致死量. $24^{\circ} \mathrm{C}$ に录ける結果

\begin{tabular}{|c|c|c|c|}
\hline $\begin{array}{l}\text { 投与ル } \\
\text { 一ト }\end{array}$ & 致死量 & 浅麻醉量 & 深麻䣷量 \\
\hline 皮下 & $300 \mathrm{mg} / \mathrm{kg} \leqq$ & $100 \mathrm{mg} / \mathrm{kg}$ & $200 \mathrm{mg} / \mathrm{kg} \leqq$ \\
\hline 腹腔内 & $223.9 \mathrm{mg} / \mathrm{kg}^{*}$ & $60 \sim 100 \mathrm{mg} / \mathrm{kg}$ & $200 \mathrm{mg} / \mathrm{kg} ?$ \\
\hline 静脤内 & $58.88 \mathrm{mg} / \mathrm{kg}^{*}$ & $30 \mathrm{mg} / \mathrm{kg}$ & $?$ \\
\hline
\end{tabular}

*ケタラール説明書から引用

c）チオペンタールナトリウム（ラポナール）

本剂は極短時間麻酔の静脈内投与麻酔剂として知られ ている。ラットでは静脈内投与は他の動物に比較して難 かしく，もっぽら皮下，腹腔内などの投与に頼らざるを 得ない。そこで若干の局所の疼痛の心配はあったが，皮 下, 腹腔内, 静脈内の投与を試みた。成績は表 4 のごと
くで初期興奮が強く, 皮下, 腹腔内では反射, 痛覚の消 失にも量と時間が必要でめった。経口投与に打いては $200 \mathrm{mg} / \mathrm{kg}$ でも反射, 痛覚が消失せず， $300 \mathrm{mg} / \mathrm{kg}$ 投 与後 1 時間です痛覚が消失せず 5 時間後には死亡した。 $60 \mathrm{mg} / \mathrm{kg}$ を経肛門投与した結果，痛覚消失せず 8 時間 後覚醒した。

表 4 Wistar-Imamichi rat に抢けるラボナール投 与の麻酔量と致死量

\begin{tabular}{l|c|c|c}
$\begin{array}{l}\text { 投与ル } \\
\text { 一ト }\end{array}$ & 致死量 & 浅麻酔量 & 深麻酔量 \\
\hline 皮 下 & $\begin{array}{r}300 \sim 400 \\
\mathrm{mg} / \mathrm{kg}\end{array}$ & $100 \mathrm{mg} / \mathrm{kg}<$ & $\begin{array}{r}200 \sim 300 \\
\mathrm{mg} / \mathrm{kg}\end{array}$ \\
\hline 腹腔内 & $100 \mathrm{mg} / \mathrm{kg} \leqq$ & $50 \mathrm{mg} / \mathrm{kg}<$ & $70 \mathrm{mg} / \mathrm{kg} \leqq$ \\
\hline 静脈内 & $70 \mathrm{mg} / \mathrm{kg}^{*}$ & $20 \mathrm{mg} / \mathrm{kg}$ & $40 \mathrm{mg} / \mathrm{kg}<$ \\
\hline
\end{tabular}

* ラボナール説明書から引用

\section{2) 吸入麻酔}

a) ハローセン

本剂はきわわて良好な麻醉效果が得られる。適当なビ ニール袋の底にボールペン大の穴を 2 ケ所あけ, 袋の中 にラットを入れる。次いでハローセンの気化器の放出口 からのチューブを袋の口に入れてロを締め，八ロー七ン ガスを送気する。

図 16 のような市販吸入器があればそれを用いる。

最初の 30 秒は $7 \%$ ，その後は $2 \%$ のガスを送気する と約 3 分間で大変良好な手術適応麻酔程度が得られ, 吸 入中止により数分で覚醒する。

手術あるいは処置をするためには深麻酔に入った状態 で吸入麻酔用ビニール袋や器具から出し, 図 17 のよう なプラスチックロートを改良した吸入マスクやラットの 鼻先が丁度入るゴムチューブのマスクに切替觉る。

もし人工呼吸器の必要がある場合はラット，モルモッ ト用の人工呼吸器（図 18）を用いれば可能である。た だし気管チューブをロから装着するには熟練が必要であ るが, エンカビニールチューブ $(6 \mathrm{~mm})$ の先を加熱し 引き伸ばしながらスポイト状に細くして三日月状に曲げ て用いれば不可能ではない。一般には気管切開により気 管にチニーブを入れ，八ローセン気化器を接続した人工 呼吸器で行なら。

前処置あるいは導入麻酔にはアトロピン，ドロペリド ール，塩酸ケタミン，ペントバルビタールナトリウムな ぞの適量を用いる。

ハローセン使用に当っては部屋の換気を十分に心掛け 
る必要がある。

b) エーテル

エーテルは麻酔用の方が結果が良い。

吸入方法は種々あるが径約 $12 \mathrm{~cm}$ 高さ約 $25 \mathrm{~cm}$ 程度 の共口蓋ないしはネジ蓋の透明なガラス瓶の底に脱脂綿 を入れ，その上に綱を 2 重に折り曲げて敷き，脱脂綿に エーテルの一定量をしみ込ませておき，その瓶の中にラ ットを入れて蓋をする。ラットの呼吸や体の状態をみて 深麻酔と思われる時に外に出し処置をする。数分間の処 置であればそのままで良いが，それ以上の時間を要する 処置では，ラットの頭部が入る程度の径の小ビンまたは 大試験管にエーテルをしみ込ませた脱脂綿を入れて鼻先 にあてがい呼吸の状態を見ながら処置をする。

この方法では麻酔瓶が不潔になりがらなため著者は $32 \times 38 \mathrm{~cm}$ のビニール袋を二重にして，その中にラット を入れ，さらにェーテルをしみ込ませた脱脂綿を入れて 袋の口を閉じ，深麻酔の状態になった時に袋からラット の頭部を残して外に引き出して処置をしている。

フローセンと同様にエーテル用の気化器を用いて吸入 させる方法もあるがあまり使用しない。

\section{2. 特殊麻酔}

\section{1）新生仔ラットの麻轱}

a) ペントバルビタールナトリウム

$31^{\circ} \mathrm{C}$ の飼育箱で生後 4 日のラットの腹腔内にペント バルビタールナトリウム（ネンブタール 10 倍液）を投 与した成績 (斉藤ら, 未発表)によると $40 \mathrm{mg} / \mathrm{kg}$ 以上 では死亡率が高く，全例生さた $30 \mathrm{mg} / \mathrm{kg}$ では麻酔効果 が良好で手術可能であったとしている。しかし覚醒はあ まり良くない。処置後は $31^{\circ} \mathrm{C}$ の保温箱に入れ体温や血 色, 運動が回復し, 術部が乾燥してから母親の巣に返す ことが大切である。

b) エーテル

適当な大ささのシャーレに濾紙またはティッシュペー パーを敷き，さらにエーテルをしみ込ませた脱脂綿を入 れ，その中に新生仔を扔いて麻酔を括こなう。エーテル に対し，新生仔は極めて麻酔されにくく，エーテルによ る体温放散のため低体温麻酔状態になるのか，本来のエ 一テル麻酔効果なのか区別が出来ないほど高濃度のエー テルガスを使用しなければ麻酔効果が得られない。

c ）低体温麻酔

ボールに食塩を $0.5 \%$ 加えた承塊を入れ，その中央に ティシュペーパーを敷いたプラスチックコップを氷塊が
入らない程度に沈め 20 分間放置する。コップの中の温 度が十分冷却した後に新生仔（毛のない間）を入れ，透 明ビニール袋で蓋をしておく。体温が約 $2^{\circ} \mathrm{C}$ 低下する と刺激に対して反応がなくなる。この時点でコップから 取り出せば $3 \sim 10$ 分間の手術可能な麻酔深度が得られ る。特に 5 分以内であれば呼吸を停止させても覚醒およ びその後の生体機能の異常は認められない。

術後は $31^{\circ} \mathrm{C}$ の保温器の中に入れて局所の乾燥之麻酔 の回復後に母親の巣に返す。

この方法を用いて新生仔ラットの下垂体摘出や胸腺の 摘出を試みたが結果は極めて良好であった。

この低体温麻酔法はラットのほかマウス，ウサギなど の新生仔にも応用できるが，その他の動物種については 今後の研究が期待される。

以上，ラットの保定と麻酔について無造作に列記した が，若干でもこの稿が扣役に立てば幸である。

終りにのぞみ写真と成績を提供して頂いた日本獣医畜 産大学, 高橋 明, 残留農薬研究所, 斉藤 徹, 動物繁 殖研究所, 若藤靖匡, 公害研究所, 高橋 弘, 本学崡学 部，色川俊則の各先生方に感謝申し上げるとともに，本 稿執筆の協力を頂いた本学医学部動物実験施設, 吉野 豊講師, 茂木国男, 安斉孝之の各獣医師に深謝する。

\section{引用 文 献}

1) 今道友則監修, 高橋和明, 信永利馬編集. 実験動 物の飼育管理と手技, ソフトサイエンス社, 東京, 1979.

2) Lums, William, V. and E. Wynnjones. Veterinary Anesthesia, Lea \& Febiger, Philadelphia, 1973.

3) 信永利馬, 高橋和明, 岡本道生, 若藤靖匡, 川西 広明. 注射による投与とその問題点（ラットを例 にあげて）免疫実験操作法， V, 免疫学会編集部 1257-1273, 1975.

4) Nobunaga, Toshima,, Katsumi, Nakamura, and Tomonori, Imamichi : A methode for intravenous injection and collection of blood from rats and mice without restraint and anesthesia. Laboratory animal care 1641, 4049, 1966.

5) Walker, Donald G. Mirian F. Jimpson, G. Willet Assling and Herbert M. Evans. Growth and differentiation in the rat Fallowing Hypophysectomy at 6 day of age. Anatomical Record, 106, 539-554, 1950. 